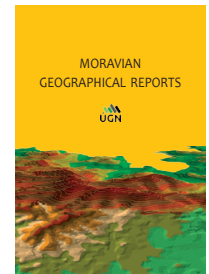

MORAVIAN GEOGRAPHICAL REPORTS

The Czech Academy of Sciences, Institute of Geonics

journal homepage: http://www.geonika.cz/mgr.html

doi: https://doi.org/10.2478/mgr-2021-0020

\title{
Central European tourist flows: Intraregional patterns and their implications
}

\author{
Martin ŠAUER ${ }^{\text {* }}$, Jiří VYSTOUPIL ${ }^{a}$, Markéta NOVOTNÁ ${ }^{a}$, Krzysztof WIDAWSKI $^{b}$
}

\begin{abstract}
Understanding tourist spatial behaviours is essential for strategic planning and sustainable development. Especially at the city-level, data provide implications for spatial planning and transport governance. Intraregional tourist flows to cities contributed significantly to the total volume of tourists within the Central European region before the COVID-19 pandemic outbreak. Given the challenges that urban tourism is currently facing, intraregional tourist flows could be a strategic opportunity for future growth. As a comprehensive assessment of the tourist flows at this spatial level is lacking, the paper aims to evaluate the structure of these flows and discuss the factors that influence their spatial distribution. Statistical data analysis of tourist flows to selected cities in Central Europe is evaluated by multiple linear regression. The results show that the main factors affecting the distribution of tourist flows are air connection, the attractiveness of the destination, and the size of the source market. Tourist flows within Central Europe are fundamentally affected by Germany. This market can be considered the most important source of demand for inbound tourism. Germany's national ties with Austria and Switzerland generated $47 \%$ of all trips examined. In this case, the influences of historical ties and the broader socio-economic context are evident.
\end{abstract}

Keywords: mobility, urban tourism, tourism development, intraregional flows, spatial analysis, Central Europe

Article history: Received 12 November 2020, Accepted 5 December 2021, Published 31 December 2021

\section{Introduction}

The essence of tourism is the movement of people in time and space. Tourists leave their home environment and head to destinations to have experiences, discover places, carry out business or search for themselves. The understanding of tourist movements is important for the development of tourist and transport infrastructure, for the development of tourism products, for the commercial viability of the tourism industry, and for managing the social and environmental impacts of tourism (McKercher and Lew, 2004).

Tourist flows reflect tourists' preferences and the result of choices they have made. In addition to the traditional demand (push) factors that explain the need to travel, we should pay attention to the supply side of tourism to explain the motives to travel (pull factors). Marrocu and Paci (2013) emphasise the fact that tourism destinations are very different in terms of travel motives. Therefore, the various features of leisure products play a crucial role in determining the flows of different tourists to different destinations.
Understanding the context of the spatial distribution of tourist flows and thus the manifestations of tourism, are prerequisites for assessing the potential for further tourism development. The knowledge of the factors that influence these flows allows stakeholders in local and regional governance and destination management to make more informed political and economic decisions (see Beritelli et al., 2020). Moreover, public policy today must respond to the challenges facing tourism. Climate change and the effects of the COVID-19 pandemic require public interventions that affect the intraregional movements of tourists. The emphasis on short journeys, environmentally friendly forms of transport, and tourists' sustainable behaviours, is becoming the new reality.

In this respect, the Central European region is a useful case study area where the development of intraregional tourist flows can be a strategic opportunity for future growth. The region's size primarily creates preconditions for revising the transport systems, and the start-up of processes associated with the shift from air transport to rail.

\footnotetext{
a Department of Regional Economics and Administration, Faculty of Economics and Administration, Masaryk University, Brno, Czech Republic (*corresponding author: M. Šauer, e-mail: sauer@econ.muni.cz)

${ }^{\mathrm{b}}$ Institute of Geography and Regional Development, University of Wrocław, Wrocław, Poland
} 
Therefore, we focus on the intraregional tourist flows within the Central European region, i.e. internal sources of demand that the region generates itself, and analyse the most important tourist flows from Central European countries to the most important Central European cities. The paper aims to evaluate the structure of these tourist flows and to discuss the factors that influence their spatial distribution. In other words, we are interested in answering the following questions:

1. How important are the tourist flows to cities within Central Europe, and what is their spatial structure?

2. What factors influence the character and spatial distribution of intraregional tourist flows, and what is the significance of the individual factors?

The contribution of the research is twofold. First, tourism in the Central European region from spatial perspectives has not been addressed at this time. Quantifying the importance of the region in European tourism and knowing the structure and volume of intraregional tourist flows, provides new insights potentially affecting tourism policy, and an opportunity for growth in the post-pandemic tourism period.

A second contribution lies in the choice of the spatial level of analysis. In our evaluations, we concentrate on a spatial nexus at the city level. Typically, regional studies are focused on higher spatial levels, mainly NUTS 2 areas. In contrast, city-level data allow us to take a more detailed view of tourist flows and set aside the heterogeneity of higher territorial units (see Yang and Wong, 2013). At the same time, urban tourism was one of the most dynamically growing segments of the industry until being hit by the COVID-19 crisis.

\section{Theoretical framework}

\subsection{Investigating tourist flows at different territorial levels}

Contemporary literature analysing tourist flows is particularly extensive (Ferrante et al., 2017). In this respect, the investigation of patterns of tourist mobility has a dominant position in scientific outputs (Šauer and Bobková, 2018). Tourist flows are usually researched among a select group of countries that dominate the international tourist market on a world scale (e.g. Williams and Zelinsky, 1970; Chung et al., 2020; Shao et al., 2020). Based on the political economy approach, tourist flows relate closely to the economic circumstances of the generating regions (Li et al., 2008). The functional approach indicates that the flows are derived from the nature of demand and supply interactions (Mansfeld, 1990).

Few studies have focused on the different geographic scales of tourist flows. From a macro-regional perspective, they investigated tourist flows among the Asia-Pacific countries (e.g. Kulendran and King, 1997; Li et al., 2008; Liu et al., 2010), or identified the structure of tourist flows within Europe (Jansen-Verbeke and Spee, 1995). A major part of the tourist flows was accounted for by tourists coming from regions within a range of $500 \mathrm{~km}$. Jansen-Verbeke and Spee (1995) confirmed that tourists were predominantly oriented towards destinations within a short distance range.

It is suggested that the extent of intraregional tourist flows can make significant tourism growth (Oppermann, 1993; $\mathrm{Li}$ et al., 2008). Therefore, more narrowly focused regional analyses also appeared in addition to the macro-regional analyses. Analysis of tourist flows at the regional level allows identifying relevant markets for the region (JansenVerbeke and Spee, 1995). Therefore, knowledge of the spatial structure of tourist flows in smaller geographical areas leads to more competitive tourism destination planning, the formulation of tourism policies, and management strategies (Liu et al., 2010; Kang et al.,2018).

From this regional point of view, the authors dealt mainly with the spatial distribution of cross-boundary tourist flows within specific countries (e.g. Oppermann, 1993; Liu et al.,2010; Peng et al., 2016) or specific regions (e.g. Hall, 1991; Hall, 2000; Williams and Baláž, 2002). On the other hand, research on tourist flows within the specific market conditions of Central and Eastern European regions was fragmented and atheoretical (Williams and Baláž, 2002). The socialist ideology, difficulties in obtaining visas, a forbidding image, and inadequate tourism infrastructure represented the main constraints on tourism growth (Hall, 1991). The organisation of tourist flows in these transition countries changed over time, mainly in scale and motivation. On the contrary, the pattern of nearest-neighbour tourist flows has changed very little since 1989 (Williams and Baláž, 2002). In 1997, almost $50 \%$ of tourist flows in Central and Eastern Europe were from other countries within the region (Hall, 2000). Before embarking on their transition, the share of intraregional tourist flows was $61 \%$. In the former Czechoslovakia in 1989, as much as $83 \%$ of tourists came from just three neighbouring countries (Williams and Baláž, 2002).

The importance of cities in Central and Eastern Europe was highlighted, as tourists remained concentrated in the capital cities due to their greater ties to the global economic system (Ivy and Copp, 1999; Baláž and Williams, 2005). The patterns of tourists overwhelmingly concentrated in the capital cities were similar to those in Third World nations (Oppermann, 1993). In contrast to the more extensive analysis of tourist flows on the international or regional level, contemporary statistics are not able to capture tourist flows at the level of individual cities (Šauer and Bobková, 2018). At the same time, urban tourism is considered by UNWTO/ WTCF (2018) to be an important segment of international tourism. According to the World Travel Monitor (IPK International, 2020), trips to cities made up close to $30 \%$ of all holiday flows in 2019. The importance of urban tourism is reflected as well in the role of tourism within the urban economy (Dumbrovská and Fialová, 2014).

Urban tourism can be a driving force for the economic, social, and spatial transformation of cities in the sense of revitalisation of public spaces, the development of public infrastructure, or interconnections of their residential and recreational functions (UNWTO/WTCF, 2018). Given the structuring of the urban environment and dynamic processes in cities (Šveda et al., 2020), it is necessary to investigate the flows to cities and find a method that would be able to estimate such flows (Šauer and Bobková, 2018). This need is amplified by the COVID-19 pandemic outbreak, which drastically affected the tourism industry in urban destinations (Novotná et al., 2021; Seyfi et al., 2021).

\subsection{Determinants of tourist flows}

Researchers are interested in tourist flows not only in terms of their patterns and intensity but also in their nature. The nature of tourist flows to regions, countries, or cities needs to be analysed further in terms of the determinants that are leading to their volumes. The existing literature has taken various factors into account, e.g. the traffic links between regions and the tourist attraction potential (Jansen-Verbeke and Spee, 1995). The nature of tourist flows may also include factors such as the socio-economic, 
psychographic characteristics of tourists, destination attributes, promotion, or marketing effectiveness, etc. (Mansfeld, 1990). Insights into tourist flows in such detail contributes to an understanding of the geographic dimension of tourism. At the city level, there are profound implications for infrastructure planning, transportation improvement, and economic growth (Xing-zhu and Qun, 2014).

To determine the nature of tourist flows, researchers have investigated variables that account for various characteristics of destination areas (supply side), as well as the characteristics of the tourists (demand side). The tourist characteristics that could shape the flows include motivation, time budgets, interests, and emotional value (Lew and McKercher, 2006). Motives that drive tourists to travel (the so-called push factors) can be divided into four groups: social gathering, education, self-reflection, and relaxation. On the other hand, the specific characteristics of a destination (the so-called pull factors) encourage tourists to visit it (Lesjak et al., 2015). Push motivations are conceived as useful for explaining the desire for travel; pull motivations are useful for explaining a tourist's destination choice (Bozic et al., 2017).

Different pull factors influencing tourist flows are considered to understand the tourist attractiveness of a destination. For destination variables, historical attractions and monuments are the most important motivators (Bozic et al., 2017). In this respect, UNESCO sites have a significant and persistent role in attracting foreign tourists and enhancing international tourism (De Simone et al., 2019). According to Reitsamer et al. (2016), infrastructure, scenery, accessibility, and local community are among the key factors of destination attractiveness. The factors generating tourist flow to a destination are other tourist attractions such as museums and galleries. Their absence can dissuade tourists from visiting a particular location (Das et al., 2007). Similarly, Krešić and Prebežac (2011) highlighted the importance of tourism superstructure, which refers to the variety of tourism facilities in which different destination activities take place (e.g. accommodations and capacities). Activities in a destination were identified as influential pull factors. In addition to recreational activities and cultural attractions, business motives including meetings, incentive travels, congresses, conventions, and exhibitions are also associated with urban tourism (Bozic et al., 2017).

Factors influencing tourist flows do not only include natural and cultural resources, infrastructure, or services in the destination. According to Jansen-Verbeke and Spee (1995), the volume of tourist flows is related directly to the major population concentrations and the economic situation in the visited destinations. As cities are places with high population density, one of the most important motives associated with their travel is visiting friends and relatives (Bozic et al., 2017). The tourism industry considers this type of tourism as a low-value market due to the personal motivations and use of unpaid accommodations (Aslan and Dinçer, 2018). The position of cities within the urban and economic structure can be measured not only by the city population but also by their gross domestic product. The income level in a destination represents an indicator of the economic development and thus may be interpreted as a proxy for the quality of the public services available for the incoming tourist flows (Marrocu and Paci, 2013).

In the case of tourist flows, the factors related to the originating country, i.e. the source market, should be investigated. The most important explanatory variables of flows to the destination are income in the originating country, the population in the market, cost of living, and other price factors such as exchange rates (Zhang and Jensen, 2007). In other words, the mechanisms that facilitate the tourist flows can be related to the origin area variables, such as the country's population size, national GDP levels, and issues related to destination competitiveness (Prideaux, 2005). According to Zhang and Jensen (2007), the variable capturing the relative price competitiveness of the individual destination is not statistically significant; on the other hand, better local purchasing power attracts tourists.

Origin-destination variables are also important factors in explaining tourist flows between pairs of countries. Marrocu and Paci (2013) mentioned the geographical distance in the kilometres between each origin and each destination area. These authors also considered accessibility based on flights and transport infrastructure. The number of direct flights between countries also contributes to increases in international tourist flows (Lohmann et al., 2009; Khan et al., 2017). From this point of view, transport infrastructure is a key element in moving the tourists efficiently nearer to the tourism product (Page, 2005). Connectivity of transport can influence the mobility of tourists and enhance the destination's accessibility. Similarly, accessibility to the destination may enhance spatial competition. Improvements in accessibility are expected to boost urban and business tourism due to a reduction of the generalised cost of transportation (Albalate et al., 2017). Moreover, the interconnection of cities is a significant factor which stimulates horizontal and vertical cooperation of cities and enhances their competitiveness (Viturka et al., 2017).

In summary, international tourist flows can be explained by the supply-side as well as demand-side variables (Zhang and Jensen, 2007). In a broader context, there is also an influence of historical ties, linguistic proximity, and other institutional perspectives that are not negligible determinants of tourist demand (Khalid et al., 2021).

\section{Data and methods}

\subsection{Study area}

The subject of this evaluation is the spatial differentiation of tourist flows within the Central European region. This region is defined by the territory of eight countries, namely the Czech Republic, Poland, Slovakia, Hungary, Austria, Germany, Switzerland, and Slovenia. The essential starting point for defining this space was the World Factbook, Encyclopedia Britannica, and others (e.g. Nováček, 2012; Šauer et al., 2019). The political and historical settings of the selected countries were also considered.

We specifically focus on urban tourism as one of the most dynamically developing and currently also one of the most affected forms of tourism. At the same time, urban tourism has contributed to the growing importance of cities in the regional economy and has been part of general processes of urbanisation. Therefore, the selection of cities for analysis was conditioned on the one hand by their attractiveness supported by supply and demand factors, and on the other hand by their complex functional size and importance in the settlement system. Certainly, a no less important aspect of the selection was the availability of statistical data on the geographical structure of inbound tourism. Based on this methodological basis for the city's evaluation (Viturka et al., 2017), some 34 most important cities in Central Europe were selected for a detailed spatial analysis at the 
city level. The cities that are further analysed are listed in Table 1. The International Standard ISO 3166 for country codes is used when referring to individual countries.

According to official statistics (UNWTO, 2021), Central Europe is, in terms of international tourist flows, the third most important region in Europe (after the Southern Mediterranean Europe and Western Europe, but ahead of Northern Europe). It is visited annually by more than 110 million foreign tourists, which represents about $21 \%$ of total foreign arrivals in Europe. Central Europe is, however, a region very open to external sources of demand. The Central European region itself (i.e. the intraregional tourist flows) generates only $35 \%$ of the total volume of tourists. The number of tourists from other parts of Europe is thus greater than the intraregional movement of tourists within the region.

The above-identified cities made up more than $70 \%$ of the tourist flows of all cities in Central Europe. From Table 2, it is theoretically possible to determine $34 \times 7=238$ tourist flows from the Central European countries to selected cities (with Slovenia having none). The most important tourist flows to cities were taken for representative evaluation, namely the flows above 50,000 arrivals in 2018. A total of 51 such flows were analysed. The following Table 2 indicates where and in what intensity these flows were headed.

A general view of the spatial arrangement of tourist flows within the Central European region is shown in the following Figure 1.

\subsection{Study design and data analyses}

To evaluate and discuss the factors that influence the spatial distribution of tourist flows within the Central European region, we process the gathered information on the number of tourists to selected Central European cities and determine their geographical origin at the level of individual countries. The data is compared with the outputs obtained from a model created based on the Guirao and Campa (2014) ranking methodology. Differences in the order of tourist flows according to the model and actual measured outputs represent the source for discussion on

\begin{tabular}{llll}
\hline Country & City & Country & City \\
\hline Austria (AT) & Vienna & Germany (DE) & Leipzig \\
Austria (AT) & Graz & Germany (DE) & Bremen \\
Austria (AT) & Linz & Germany (DE) & Dresden \\
Austria (AT) & Salzburg & Germany (DE) & Nuremberg \\
Austria (AT) & Innsbruck & Hungary (HU) & Budapest \\
Czech Republic (CZ) & Prague & Poland (PL) & Warsaw \\
Czech Republic (CZ) & Brno & Poland (PL) & Krakow \\
Czech Republic (CZ) & Ostrava & Poland (PL) & Wroclaw \\
Czech Republic (CZ) & Pilsen & Poland (PL) & Poznań \\
Czech Republic (CZ) & Karlovy Vary & Poland (PL) & Gdansk \\
Germany (DE) & Berlin & Poland (PL) & Szczecin \\
Germany (DE) & Hamburg & Slovakia (SK) & Bratislava \\
Germany (DE) & Munich & Slovenia (SI) & Ljubljana \\
Germany (DE) & Cologne & Switzerland (CH) & Zurich \\
Germany (DE) & Frankfurt & Switzerland (CH) & Geneva \\
Germany (DE) & Stuttgart & Switzerland (CH) & Basel \\
Germany (DE) & Düsseldorf & Switzerland (CH) & Bern \\
\hline
\end{tabular}

Tab. 1: Selected cities of Central Europe

\begin{tabular}{lccccc}
\hline \multirow{2}{*}{$\begin{array}{l}\text { Intensity of flows } \\
\text { from: }\end{array}$} & \multicolumn{5}{c}{ Number of arrivals in thousands } \\
\cline { 2 - 6 } & Above 50 in total & $50-100$ & $100-200$ & $200-500$ & over 500 \\
\hline Austria (AT) & 7 & 3 & 3 & 1 & 0 \\
Czech Republic (CZ) & 4 & 2 & 2 & 0 & 0 \\
Germany (DE) & 20 & 8 & 7 & 3 & 2 \\
Hungary (HU) & 2 & 0 & 2 & 0 & 0 \\
Poland (PL) & 6 & 2 & 3 & 1 & 0 \\
Slovakia (SK) & 2 & 1 & 0 & 1 & 0 \\
Slovenia (SI) & 0 & 0 & 0 & 0 & 0 \\
Switzerland (CH) & 10 & 6 & 2 & 2 & 0 \\
Total flows & $\mathbf{5 1}$ & $\mathbf{2 2}$ & $\mathbf{1 9}$ & $\mathbf{8}$ & $\mathbf{2}$ \\
\hline
\end{tabular}

Tab. 2: Intensity of tourist flows from eight Central European countries to selected cities (2018) Source: authors' compilation 


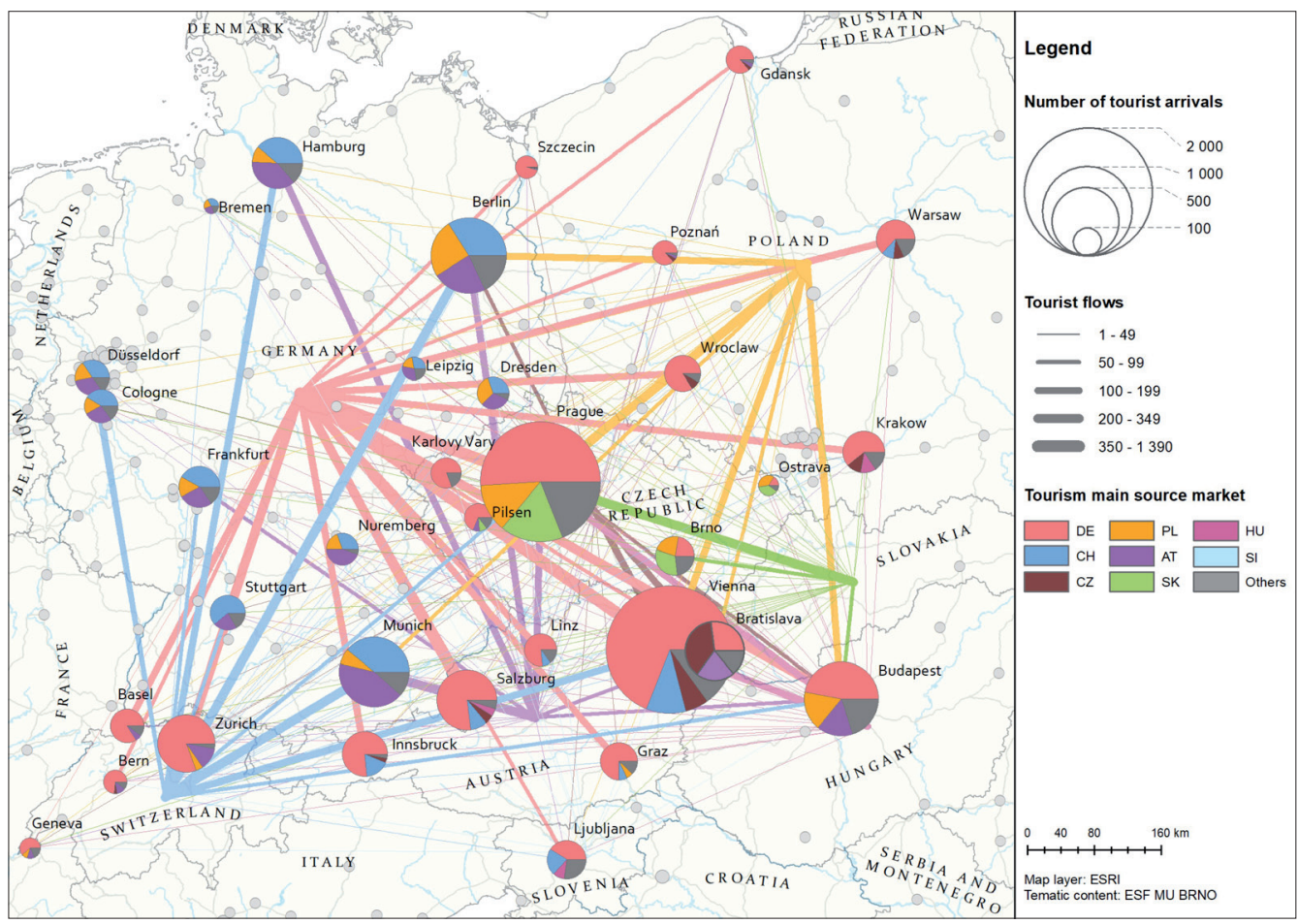

Fig. 1: Tourist flows to the most important cities of Central Europe

the impact of individual analysed variables. Furthermore, the interpretation of the obtained results is supported by the application of a multiple linear regression model, which quantifies the potential importance of the assumed factors. The whole process involves several follow-up steps.

\subsubsection{Spatial analysis of tourist flows to selected cities}

The following Central European countries are selected for the analysis of the inbound/outbound origin-destination (O-D) matrices: Czech Republic (CZ), Germany (DE), Poland (PL), Austria (AT) and Hungary (HU), Slovakia (SK), Slovenia (SI) and Switzerland (CH). With respect to the applied statistical methodology, the number of foreign arrivals to selected countries is measured using the UNWTO category "TCE: arrivals of non-resident tourists to all types of collective accommodation establishments". The basic source of these comparative analyses is the TourMIS (2019, data for 2018) and the UNWTO (2019) Yearbook of Tourism Statistics (selected data for 2017), supplemented by other statistical and information sources and portals of national and regional or municipal statistical offices, and tourist organisations, namely: Slovenian Tourist Board (STB, 2019), the Statistical Office of the Slovak Republic (SOSR, 2019), the Federal Statistical Office of Germany (Destatis, 2019) and annual reports of selected federal states, the Czech Statistical Office (CZSO, 2019), the Hungarian Central Statistical Office (HCSO, 2019), Statistics Austria (2019), Statistics Poland (2019), and the Swiss Federal Statistical Office (FSO, 2019).

\subsubsection{Identification of the factors influencing tourist flows and their operationalisation via selected variables}

In connection with the spatial distribution of tourist flows, we assume four main areas that might have an impact on the flows. As outlined in the literature review, they are: (1) the tourist attractiveness of a destination and its surroundings; (2) the importance of the source market; (3) accessibility; and (4) the economic importance of the visited city.
1. Tourist attractiveness of the destination and its surrounding

To better interpret the results of our spatial analysis, we supplement the analysis with an assessment of the level of attractiveness for tourists of the most important Central European cities. For this purpose, we define two variables. The first variable is a point evaluation of the city attractiveness. The city attractiveness is based on a composite indicator, which consists of four sub-indicators of the tourism supply mentioned in the scientific literature: the presence of cultural and historical monuments on the UNESCO list, the presence of important galleries and museums, the evaluation of the MICE (Meetings, Incentives, Conference/Conventions and Exhibitions) tourism segment, and the capacity of collective accommodation establishments. All sub-indicators are standardised on a three-point scale: significantly above-average, average, and below-average significance. The evaluation of the galleries and museums is based on the collection of statistics on museums in Europe (Eurostat, 2019). The MICE rating is based on the number of congresses in the city and their attendance (ICCA, 2019). When evaluating the significance of UNESCO World Heritage Site (UNESCO, 2021), the extent of territorial protection is considered (e.g. the difference between a freestanding monument and the historical centre). The last sub-indicator is evaluated according to the number of bed capacities in collective accommodation establishments in the city (Eurostat, 2021a). The composite indicator is a weighted average of these four sub-indicators: the presence of UNESCO (40\%), museums and galleries (20\%), MICE (20\%), and number of bed capacities (20\%).

The second variable is the evaluation of city surrounding's attractiveness. In this case, we work on the number of visits to the NUTS 2 region, in which a particular city belongs (the exception is the Czech Republic, where the number of visits to NUTS 3 regions is evaluated). The variable is designed as several overnight stays per $\mathrm{km}^{2}$ (nights_region) and does not include the impact of the city itself. The data were 
obtained from the Eurostat (2021b) dataset on the number of overnight stays in NUTS 2 regions. In the case of the Czech Republic, the data comes from the Czech Statistical Office (CZSO, 2019).

\section{The importance of the source market}

The capacity of demand is observed based on a traditional variable, which is the adult population of the source country of demand. We assume the population over 20 years of age (the variable is pop20+) is sufficient. The data were obtained from the Eurostat statistics on population (Eurostat, 2021c; Eurostat, 2021d). Another variable in this category is the index GDP per capita ( $g d p \_$index). It is compiled as a ratio of the Destination GDP per capita (PPP) and Origin GDP per capita (PPP). In both cases, numerator and denominator include the values for the whole country. The data were obtained from Eurostat (2021e), specifically, the data on GDP per capita in the purchase power parity. The aim of the variable is to take into consideration the purchasing power of individual source countries.

\section{Accessibility}

The accessibility is also evaluated by means of two variables. The first is the distance between the source and target destinations (distance). We used the Mayer and Zignago's (2011) approach to determine the distance between various spatial units (country, city), and modified their general formula to fit the relation country - city. The core is the calculation of the average distance between city $i$ and functional urban areas $k$ in the country $j$ and their weighted amount of population (Eurostat, 2021f).

$$
d_{i j}=\sum_{k=1}^{n} \frac{p_{k j} \cdot d_{i k}}{\sum_{k=1}^{n} p_{k j}}
$$

where $d_{i j}$ is an average distance between the city $i$ and the country $j, p_{k j}$ is the amount of population of the functional urban area $k$ in the country $j$, and $d_{i k}$ is a distance between city $i$ and the functional urban area $k$. Individual distances were modelled based on network analysis in a geographical information system.

Another variable that characterises the importance of the availability of the evaluated city is the number of flights (flights) that the local airport handled in 2018, both arrivals and departures (Eurostat, 2021g). This parameter characterises the connectivity of the studied cities to the countries of the Central European region. The flights have been included in the model because the distance itself in the present developed transport network does not have to play just one role. The importance of air transport within tourism is growing, and in several instances, it is the driver of the development of urban tourism.

\section{Economic importance of destination (city)}

The last category of factors includes the variables that operationalise the position of cities within the urban and economic structure of Central Europe. We work on the assumption that the more extensive and more advanced the destination is, the better quality and more diverse spectra of services it offers - it includes a higher number of urban functions. Naturally, various functions attract various types of mobilities and are also reflected in the differentiation of demand segments. We measure the economic importance by means of GDP per capita variable in the purchase power parity ( $g d p \_$city). The data were obtained from the Eurostat (2021h) and its METROREG dataset published by GDP on behalf of metropolitan regions. Furthermore, as a proxy of the economic importance of a destination, the variable 'city population' (pop city) was used. Data on European cities were collected in the Urban Audit project and is integral to the city statistics from the Eurostat (2021i). Table 3 presents data sources for each independent variable.

\subsubsection{Creating the ranking model}

The methodology of the model assumes that the eight above-mentioned independent variables determine the value of the ranking index (RI), which evaluates the importance of tourist flows. The ranking index is usually calculated as a weighted average of standardised values of individual variables (Guirao and Campa, 2014). The general formula for this rule is as follows:

$$
R I_{i j}=\beta_{1} v 1_{i j}+\beta_{2} v 2_{i j}+\beta_{3} v 3_{i j}+\cdots+\beta_{n} v n_{i j}
$$

where $\beta_{(1-n)}$ are the values for individual variables, whereas $\sum_{i=1}^{n} \beta_{\mathrm{n}}=1$; and $v n_{i j}$ is $n$ variable for a target destination $i$ and a source country $j$.

In our case, we decided to determine the same value for each variable, or, not to assume the values in the model. For example, Guirao and Campa (2014) determine the values randomly, without explaining the values. The values determined randomly make the model rather doubtful, with a certain level of subjectivity.

\section{(1) Multiple linear regression}

Only variables that are statistically significant are included in the final model. We use the method of multiple linear regression to determine the importance of individual variables and analyses of relations between them. The identified number of arrivals is the dependent variable, and the set of independent variables includes the eight above-mentioned factors that influence the spatial distribution of tourist flows. The general expression of multiple linear regression is as follows:

$$
Y_{i j}=b_{0}+b_{1} v 1_{i j}+b_{2} v 2_{i j}+b_{3} v 3_{i j}+\cdots+b_{8} v 8_{i j}
$$

where $Y_{i j}$ is the dependent variable of arrivals to destination $i$ from the source country $j, b_{0}$ is a constant, the values $b_{1}, b_{2}$, $b_{3}, \ldots b_{8}$ are partial regression coefficients, and $v 1_{i j}, v 2_{i j}, v 3_{i j}$, $\ldots v 8_{i j}$ are the values of independent variables.

To find the most appropriate model, we used the backward method, where all independent variables are first inserted into the model and the calculation algorithm then eliminates those variables that are not statistically significant.

\subsubsection{Comparison of results obtained from the model with the spatial distribution of tourist flows to selected cities}

In the last step, we compared the results of the model and actual arrivals. We evaluate the correlation at the level of categories determined according to the importance of the tourist flows. The significance categories sort out tourist flows according to their amount based on the Jenks natural breaks classification method. In total, five significance categories were created. To measure the correlation, we applied Spearman Rank Correlation analysis.

The following evaluation is based on the determination of such relations, either overvaluing or undervaluing the model (change is $\geq 2$ levels), or they shift the given relation by one category higher or lower. In such cases, the distribution of tourist flows is probably affected by other factors than those used in the analysis. 


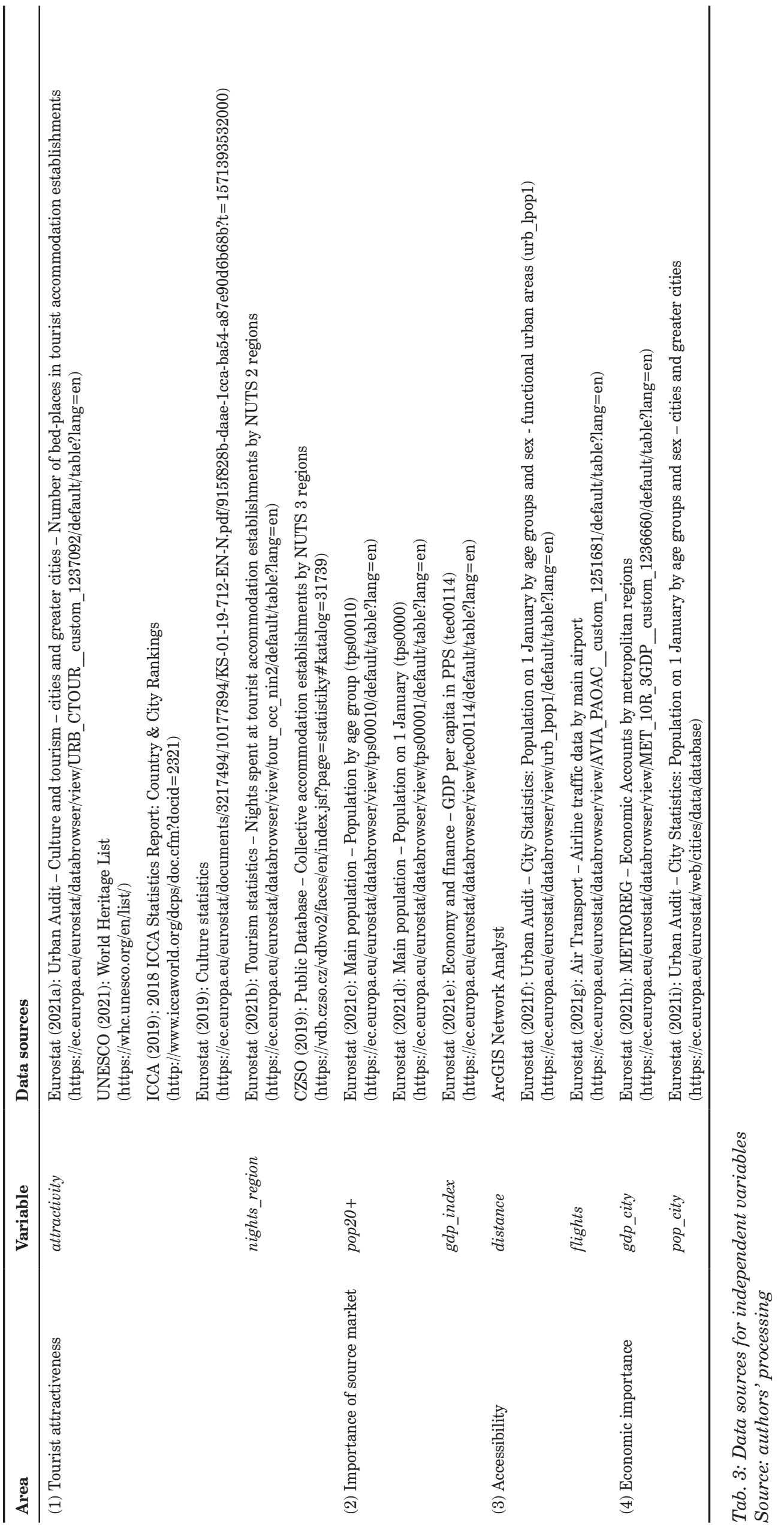




\section{Results of spatial analysis of tourist flows to cities and their determinants}

The role of cities in intraregional tourism performance is significant. If we consider the selected cities (34), the tourist flows into them represent $17 \%$ of Central Europe's tourism performance. If we assess urban tourism, however, then we estimate that trips to cities account for about $40 \%$ of all Central European tourist flows. For example, 2.42 million tourists from the above-mentioned Central European countries came to regional cities in the Czech Republic in 2018, which accounted for $60 \%$ of all arrivals in the Czech Republic. Similarly, in the case of voivodship cities in Poland, this share was $40 \%$. In 2018, this share reached 35\% in the 14 largest German cities (over 500,000 inhabitants).

Tourist flows to cities in the area reflect the form and structure of tourist flows to regions. Germany's strong dominance as a source country is confirmed, which fundamentally affects the character of internal Central European tourism. Germany accounts for $40 \%$ of the monitored flows, representing $45 \%$ of the visits of the cities surveyed. Switzerland has a $20 \%$ share of the total number of flows, but it generates only $15 \%$ of arrivals. This suggests that, although these are more numerous flows mainly to Germany, they are mostly low in volume. Austria ranks third in departures to cities (14\% share of flows and $12 \%$ of visits) and Poland ( $10 \%$ share of visits) is fourth. A total of 10.6 million foreign tourists from Central European countries went to the 34 Central European cities, i.e. more than $27 \%$ of all 38.9 million foreign tourists from eight Central European countries. If we added the available data from other regional cities (regional, voivodship, federal and cantonal), we would approach the border of 14-15 million foreign tourists to administrative centres.

Destinations are dominated by capitals (see Fig. 2). The first four positions are held by the capitals of Austria, the Czech Republic, Germany, and Hungary. Next in line are cities that represent culturally social and commercially important centres in German-speaking regions in western Austria, as well as Switzerland and Germany (Munich, Salzburg, Zurich, Innsbruck, etc.). Second-ranked cities (Camagni et al., 2015), also appear in the foreground, attracting the attention of tourists as secondary centres of commerce (Hamburg, Brno, Graz) or with strong cultural and historical potential (Krakow).
The strongest tourist flow within Central Europe is the departure of Germans to Vienna. There were 1.4 million such trips in 2019. The second strongest flow also comes from Germany, but this time to Prague, with a strength of $65 \%$ of the strongest Central European flow. Other strong tourist flows also have a source in Germany and head to Salzburg and Zurich. The strength of these flows approaches the first "non-German" flow from Slovakia to Prague. German departures to Budapest and Swiss to German cities (Berlin, Munich) are also important. The connection of the Austrians to Munich and the Poles to Prague is similar. The volume of journeys above 150,000 arrivals is recorded at Innsbruck (Germans), Berlin (Poles, Austrians), Vienna (Swiss) and Hamburg (Swiss). The strongest tourist flow from the Czech Republic is to Vienna, closely followed by Bratislava.

Overall, Vienna (2 million arrivals) and Prague (1.8 arrivals) are the most popular urban destinations for Central European travellers. Other cities lag significantly. Berlin attracts one million fewer tourists from Central Europe than Prague, with a similar situation for Budapest (1.1 million arrivals compared to Prague). Munich is still in the top five. Salzburg, Zurich, Bratislava, and Hamburg also account for four to three percent of the total number of tourists to the surveyed cities from Central Europe. The Polish and Slovenian capitals are in the middle of the rankings. In general, Polish cities lag the tourism performance of cities from the Czech Republic (influence of Prague), Germany or Austria.

\subsection{Factors determining spatial behaviours}

To interpret the factors determining the spatial behaviour of cross-border tourists within the Central European region, we have created a basic ranking model. In accordance with the methodology, we first evaluate the suitability of using eight selected variables. Through multiple regression, we identify those variables that enter the final model. The number of Central European arrivals in cities forms the dependent variable, and individual factors (pop_city, gdp_ city, pop $20+$, nights region, distance, attractivity, flights person, gdp_index) form the independent variables.

The backward method identified three statistically significant variables (see Tab. 4). They are the flights variable (0.54), the attractivity and pop20+ variables. These are therefore the three most important factors which, according to the regression analysis, result in the distribution of inbound trips to cities.

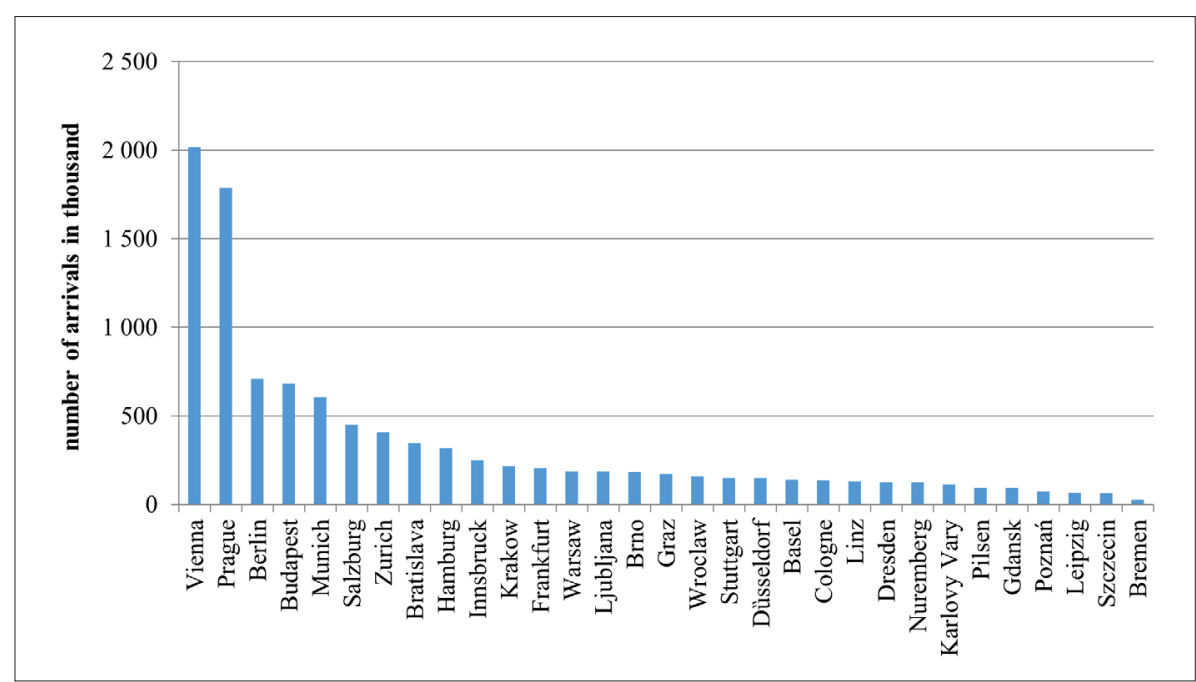

Fig. 2: The most important tourist flows to Central European cities (2018)

Source: authors' processing based on TourMIS (2019), CZSO (2019) 


\begin{tabular}{|c|c|c|c|c|c|c|}
\hline \multirow[t]{2}{*}{$\mathrm{N}=238$} & \multicolumn{6}{|c|}{$\begin{array}{l}\text { Regression Summary for Dependent Variable: } \\
\text { arrivals (dataset_flow_v2) } R=0.76 ; R^{2}=0.57 ; \text { Adjusted } R^{2}=0.56 \mathrm{~F}(3.227)=100.36 \mathrm{p}\end{array}$} \\
\hline & $b^{*}$ & Std.Err. of b* & $\mathrm{b}$ & Std.Err. of b & $\mathrm{t}(227)$ & $\mathrm{p}$-value \\
\hline Intercept & & & -53.214 & 11.025 & -4.827 & 0.000 \\
\hline Attractivity & 0.276 & 0.046 & 47.435 & 8.630 & 5.811 & 0.000 \\
\hline pop20+ & 0.201 & 0.049 & 0.000 & 0.000 & 4.141 & 0.001 \\
\hline Flights & 0.536 & 0.051 & 0.011 & 0.001 & 10.605 & 0.000 \\
\hline
\end{tabular}

Tab. 4: Regression summary for dependent variable: arrivals Source: authors' processing

Basically, these results correspond to the general idea of factors influencing the number of city visits. The development of air transport (low-cost transport) is an important predictor of tourist arrivals in cities (see Albalate and Fageda, 2016). Less important, yet still fundamental, is the impact of city attractiveness. Tourist attractiveness based on tourism supply is the main factor that attracts the attention of potential tourists (so-called pull factor). Likewise, the size of the source market proved to be very important here, and so is Germany as a source of demand.

The impact of other variables is very limited, which is surprising, particularly for the variable "distance". It has a negative value (therefore, an indirect relation between the amount of demand and distance of a source market applies here); however, it does not have any fundamental impact on the number of visits. In this context, we can speak about two main factors. The first is material, linked with the importance of air transport for urban tourism, i.e. the impact of distance is declining owing to development and accessibility. The second is methodological, connected with measuring the distance between various space levels (in our case, it is the relation city - country). The weighted average can significantly distort the real accessibility of destinations, particularly in large cities, since the capacity of demand is influenced by the significance of ties (mainly, close border agglomerations which are, on average, disappearing).

The adequacy of the whole model is evaluated based on $R$ Square $\left(R^{2}\right)$ and Adjusted $R^{2}$. In our case, $R^{2}$ equals 0.57 . It implies that $57 \%$ of the variance of the dependent variable is explained by the variables selected by us. Considering the size of the dataset, the Adjusted $\mathrm{R}^{2}$ is similar, and it does not change the interpretation. The results show that there is still relatively large space for the inclusion of other factors. Such factors are very difficult to be quantified and operationalised, however. They include the impact of historical and cultural ties, travels with the aim to visit friends and relatives, or a destination image factor.

Based on the results of the regression analysis, we compiled a simple ranking model that considers only the three most important variables (pop20+; attractivity; flights). The results are presented in Table 5. The table shows the thirty most significant identified flows. Besides the score obtained from the model, the table also includes the values of all arrivals from the Central European countries and their categorisation according to their significance (based on Jenks natural breaks classification method).

The general informative quality of the model, as well as the factors, is quite good. If we compare the ranking of visits to the cities obtained from the statistics on tourism and the model, then the Spearman Rank Order Correlations reach the value of 0.74 . Naturally, the order of individual tourist flows differs; however, the basic patterns of the spatial behaviour of Central European travellers becomes evident here. Primarily, it is the importance of Germany as a source market vital for both nearby destinations in Austria and Switzerland and all capitals of the surveyed countries. A very close relation between Switzerland and Austria also shown to exist here. The model assigns higher importance to Poland as a source country, which may, to a certain extent, cause the insufficiently used capacity of the Polish market.

\begin{tabular}{|c|c|c|c|c|}
\hline Rank & Flow & Score & Arrivals & Category \\
\hline 1 & DE - Vienna & 2.94 & 1,390 & 1 \\
\hline 2 & DE - Prague & 2.27 & 913 & 1 \\
\hline 3 & DE - Zurich & 2.27 & 317 & 2 \\
\hline 4 & DE - Budapest & 2.05 & 289 & 2 \\
\hline 5 & DE - Warsaw & 1.92 & 118 & 3 \\
\hline 6 & DE - Salzburg & 1.85 & 346 & 2 \\
\hline 7 & DE - Krakow & 1.67 & 118 & 3 \\
\hline 8 & DE - Wroclaw & 1.58 & 134 & 3 \\
\hline 9 & PL - Vienna & 1.54 & 132 & 3 \\
\hline 10 & PL - Prague & 1.54 & 232 & 2 \\
\hline 11 & DE - Basel & 1.52 & 118 & 3 \\
\hline 12 & DE - Geneva & 1.49 & 33 & 5 \\
\hline 13 & DE - Graz & 1.48 & 129 & 3 \\
\hline 14 & CH - Vienna & 1.37 & 193 & 3 \\
\hline 15 & DE - Ljubljana & 1.35 & 76 & 4 \\
\hline 16 & DE - Brno & 1.33 & 40 & 5 \\
\hline 17 & PL - Munich & 1.29 & 50 & 4 \\
\hline 18 & $\mathrm{DE}$ - Bratislava & 1.28 & 80 & 4 \\
\hline 19 & DE - Bern & 1.26 & 50 & 4 \\
\hline 20 & DE - Gdansk & 1.26 & 82 & 4 \\
\hline 21 & PL - Berlin & 1.26 & 181 & 3 \\
\hline 22 & PL - Budapest & 1.25 & 100 & 3 \\
\hline 23 & PL - Frankfurt & 1.22 & 33 & 5 \\
\hline 24 & DE - Poznań & 1.20 & 65 & 4 \\
\hline 25 & $\mathrm{CH}$ - Berlin & 1.18 & 242 & 2 \\
\hline 26 & CZ - Vienna & 1.17 & 115 & 3 \\
\hline 27 & DE - Linz & 1.15 & 102 & 3 \\
\hline 28 & AT - Prague & 1.15 & 143 & 3 \\
\hline 29 & HU - Prague & 1.15 & 106 & 3 \\
\hline 30 & $\mathrm{CH}$ - Prague & 1.14 & 77 & 4 \\
\hline
\end{tabular}

Tab. 5: Ranking model - Thirty most important tourist flows. Source: authors' processing 
A detailed analysis of the individual tourist flows generated by the model is analysed by the comparison of individual relations into categories of significance.

From the total number of 238 relations, the model significantly overvalues or undervalues nine tourist flows (see Tab. 6). The model overvalues or undervalues, only slightly (shift by one category), the other 30 relations.

The model significantly overvalues trips from Germany to Brno and Geneva and from Poland to Frankfurt. The model significantly undervalues relations between the Czech Republic and Slovakia and the Swiss and Austrians with Hamburg. Therefore, impacts and factors other than those specified in the model will be relevant here - for example, cultural proximity and historical ties. The same hypothesis may be also applied for relations between Switzerland as a source country and German cities, such as Düsseldorf, Cologne and Stuttgart, or, between Austria and Bratislava or Slovakia and Brno.

The distance factor in the model does not exhibit the expected results. Even though the regression analysis indicates an inverse relation between distance and arrivals (negative regression coefficient $b$ ), the significance of this variable is weak. It probably appears also in the results when the model either undervalues or overvalues close relations. The reason for that might lie in the above-mentioned construction of this variable (weighted average of the distance from the main agglomerations of the given country).

\section{Discussion}

Although the objects of the analysis are the most important cities in the region, the results still show a high level of unevenness of tourist flows to cities. This is perhaps not surprising, as tourism is, by its nature, a significantly differentiated phenomenon. Explaining the differences and consequences for future development is the primary motivation of this paper. Tourist flows represent a kind of materialisation of the interaction between the supply and demand factors affecting tourism. Unlike Zhang and Jensen (2007), we focus on supply-side factors and on demand variables. We consider this approach to be very important.

In the case of Central Europe, it proves to be a significant influence on the size and importance of source markets, the transport accessibility of localities, and the effect of the very attractiveness of destinations. These results are broadly consistent with Jansen-Verbeke and Spee (1995), who point to the impact of the source market's population size. Another factor, the number of direct flights between the original countries and cities, also contributes to the importance of international tourist flows (Lohmann et al., 2009; Khan et al., 2017). This is mainly due to low-cost flights, which brought new segments to cities and more frequent and more varied connections (Kraft and Havlíková, 2016). The importance of air transport in the number of tourists to cities and the geographical proximity of such links has increasingly relevant consequences today. Measures in response to climate change, as well as changes in travellers' preferences, are already leading to pressure for changes in transport modes. The development of railway infrastructure, especially the implementation of high-speed transport systems in practice, is undoubtedly a challenge for the future. Both Europe's transport policies and indeed the EU's activities in the Green Deal emphasise these issues.

The last important factor is the tourist attractiveness of the destinations. Attractiveness has always been the focus of several authors (Bozic et al., 2017; Krešić and Prebežac, 2011), who evaluate the historical value of destinations or the 'equipment' of tourist sites with tourist

\begin{tabular}{|c|c|c|c|}
\hline \multicolumn{2}{|l|}{ By at least 2 levels } & \multicolumn{2}{|l|}{ By 1 level } \\
\hline Significantly overvalues & Significantly undervalues & Overvalues & Undervalues \\
\hline DE - Brno & $\mathrm{CH}$ - Munich & DE - Warsaw & $\mathrm{CH}$ - Berlin \\
\hline PL - Frankfurt & AT - Munich & DE - Krakow & DE - Innsbruck \\
\hline \multirow[t]{17}{*}{$\mathrm{DE}$ - Geneva } & SK - Prague & DE - Wroclaw & HU - Vienna \\
\hline & $\mathrm{CH}$ - Hamburg & PL - Vienna & AT - Berlin \\
\hline & AT - Hamburg & DE - Ljubljana & SK - Budapest \\
\hline & $\mathrm{CZ}$ - Bratislava & PL - Munich & PL - Bratislava \\
\hline & & DE - Bratislava & CH - Düsseldorf \\
\hline & & DE - Bern & AT - Bratislava \\
\hline & & DE - Gdansk & SK - Brno \\
\hline & & DE - Poznań & $\mathrm{CH}$ - Cologne \\
\hline & & PL - Salzburg & $\mathrm{CH}$ - Stuttgart \\
\hline & & SK - Vienna & \\
\hline & & SI - Prague & \\
\hline & & SI - Vienna & \\
\hline & & DE - Ostrava & \\
\hline & & HU - Berlin & \\
\hline & & PL - Hamburg & \\
\hline & & PL - Dresden & \\
\hline & & PL - Bremen & \\
\hline
\end{tabular}

Tab. 6: Relation with the change of order

Source: authors' processing 
infrastructure. All these factors are applied in our analyses and significantly affect the size of tourist flows. In principle, this is a traditional factor, which was the subject of research in the first geographically oriented research in tourism (Häufler, 1955).

On the other hand, we did not demonstrate the influence of price factors (differences in price levels), nor the effect of factors of city size and their economic maturity. Zhang and Jensen (2007) reached the same results in terms of price competitiveness. Some studies do consider the relative economic position of the destination as an important factor. For example, Marrocu and Paci (2013) assume that the high elasticity of destination GDP indicates that favourable economic development and is enhanced by the availability of public services in the visited locations.

A more detailed analysis of the individual relations of cities to source markets can shed more light on the interpretation of the main factors influencing tourist flows in Central Europe. Two types of cities in the region have different market positions. By the thesis of hybrid processes and the application of path-dependent pathcreation tourism development during the transition years (Baláž and Williams, 2005), we can emphasise the different involvement of the studied cities in global processes. On the one hand, there are cities (dominantly) in the western half of the examined region, well connected to the surrounding world and acting as important sources of demand (Germany, Switzerland, Austria). On the other hand, there are many cities in the region that must rely on their traditional longterm markets. The dynamics of their development depend on the situation in the immediate vicinity (the market proximity factor dominates). In this case, tourist flows are constituted around existing networks, and deep-rooted social routines and a path dependency trajectory are manifested. These are mostly second-order cities that lack strong links to a broader range of source markets within the region.

On the contrary, well-anchored cities, which often have the status of capitals (Prague, Budapest), can abandon the original models, and radically reposition themselves in global markets (path creating). The identified factors play a role in these processes. Air transport, cities' attractiveness and connections to the most important markets create benefits for already established destinations. Low sensitivity to price competitiveness or destination GDP results from barriers and limits that lock destinations in the region's traditional model of spatial position. Barriers and limits can be found both in the mentioned social routines and in the historical-political ties and differences of the monitored destinations. An equally important factor can be the level of availability, image, and other variables. An excellent example of the manifestation of such barriers and limits is the low connection of Polish cities with the rest of the region (except Germany). For example, knowledge of Wroclaw as an important economic centre of Poland is negligible in the Czech population, business contacts are not significantly exceptional, and transport connections are unsatisfactory.

\section{Conclusions}

An analysis of the visits between Central European countries has shown that the region is one of the important objectives of contemporary tourism but is lagging its potential. It is in third place in the ranking of the sub-regions of Europe, well behind southern and western Europe. On the other hand, there are substantial internal resources from which the region's tourism can draw. Undoubtedly, this is the territory's attractiveness due mainly to the presence of the Alpine region and the localisation of major urban destinations. Border tourism must also not be neglected, but this is not always reflected in the performance of collective accommodation establishments (excluding one-day visits). An important factor is also the region's population size, which offers an opportunity for intraregional mobility: only about one third of the share of Central European tourists is seen in the performances of Central Europe. This ratio is significantly below the similar ratio in the case of European tourists in Europe (they account for 78\%). Similar results are based on a comparison of the volume of visits made to the region's population. In Europe as a whole, this indicator is 0.55 (415 million arrivals per 750 million inhabitants), and in the Central European region, this figure is less than half $(0.24)$. These processes are even more robust in the case of urban tourism. The tendency to globalise links to the external environment is a natural feature of urban development. Cities are more strongly integrated into global value chains; they are centres of international trade and therefore destinations for business travel. Moreover, they have good accessibility and are well connected to remote source markets because of air infrastructure.

How to interpret these data? Tourism and its performance are not minor in Central Europe, but relative to the population and their purchasing power, there is the potential to activate the region's internal resources. The 160 million inhabitants of Central Europe make their journeys mainly outside their own region. In today's globalised and interconnected world, this is a natural phenomenon. The world's current problems, whether it be the short-term impact of the COVID-19 pandemic or the significantly deeper problems of climate change, however, are causing the need for changes in travel behaviours towards sustainable development. This is a departure from quantitative development, based on the continuous growth of visits to the inclusion of qualitative components of consumption and an emphasis on local and regional tourism (travel within the region and in the vicinity, elimination of carbon footprints, etc.).

When we assess the interactions between the countries monitored, there is still a clear boundary between the western parts of the region and the post-socialist countries. Germany's national ties with Austria and Switzerland generate $47 \%$ of all trips examined. Interactions between Germany and the Czech Republic (1.3 million trips between them), and Germany and Poland (1 million mutual trips), follow closely. The strongest non-German interaction is between the Czech Republic and Slovakia. Intraregional flows within the examined cities of the Czech Republic, Hungary, Poland, and Slovakia, known as the Visegrad Group (V4), are negligible, making up only $3 \%$ of the total volume of visits. This is also because the Czech Republic or Poland are more strongly connected to Germany than to their V4 neighbours and the weak position of Polish cities in intraregional interactions. The Czech Republic also benefits from its location and the attractiveness of Prague, and is a kind of bridge between the west and east of the region.

There are three main factors behind the distribution of tourist flows in Central Europe. The most important is the air connection, which is playing an increasingly important role in international tourism. An equally important factor is the actual attractiveness of the destination. Tourists to Central Europe are dominated by capital cities and selected attractive second-rank cities (Wroclaw, Krakow, Salzburg, 
Graz, Nuremberg, Brno, and others). The third crucial factor is the size of the source market and corresponds to Germany's above-mentioned influence on traffic and its spatial distribution.

Indirectly, we have showed the importance of factors that cannot be well quantified. It is mainly the influence of cultural and historical ties, but also broader socio-economic contexts. In our case, we are talking about relations between the Czech Republic and Slovakia, and Switzerland with selected German cities. Undoubtedly, the close distance between Bratislava and Austria, or between Slovakia and Brno, is also essential.

Global tourist systems and their interconnection by air transport are strongly reflected in the visits to cities. Therefore, the development of intraregional visits must be oriented towards the strong links of geographically close metropolises. Location, accessibility, tourist attractiveness of the destination and strength of ties, determine the potential of tourist mobility. The connection of the main sources of demand in the west of the region with attractive locations in the east is the promise of further development of tourism in the region.

\section{Acknowledgement}

This article is an output of the project: "New Mobility High-Speed Transport Systems and Transport-Related Human Behaviour”, Reg. No. CZ.02.1.01/0.0/0.0/16 026/000 8430, co-financed by the "Operational Programme Research, Development and Education".

\section{References:}

ALBALATE, D., CAMPOS, J., JIMÉNEZ, J. L. (2017): Tourism and high speed rail in Spain: Does the AVE increase local visitors? Annals of Tourism Research, 65: 71-82.

ALBALATE, D., FAGEDA, X. (2016). High speed rail and tourism: Empirical evidence from Spain. Transportation Research Part A: Policy and Practice, 85: 174-185.

ASLAN, S., DINÇER, M. Z. (2018): A Conceptual Framework of Visiting Friends and Relatives. Journal of Tourismology, 4(1): 21-34.

BALÁŽ, V., WILLIAMS, A. M. (2005): International tourism as bricolage: an analysis of Central Europe on the brink of European Union membership. International Journal of Tourism Research, 7(2): 79-93.

BERITELLI, P., REINHOLD, S., LAESSER, C. (2020): Visitor flows, trajectories and corridors: Planning and designing places from the traveller's point of view. Annals of Tourism Research, 82: 1-13.

BOZIC, S., KENNELL, J., VUJICIC, M. D., JOVANOVIC, T. (2017): Urban tourist motivations: why visit Ljubljana? International Journal of Tourism Cities, 3(4): 382-398.

CAMAGNI, R., CAPELLO, R., CARAGLIU, A. (2015): The Rise of Second-Rank Cities: What Role for Agglomeration Economies? European Planning Studies, 23(6): 1069-1089.

CHUNG, M. G., HERZBERGER, A., FRANK, K. A., LIU, J. (2020): International Tourism Dynamics in a Globalized World: A Social Network Analysis Approach. Journal of Travel Research, 59(3): 387-403.

CZSO (2019): Public Database [statistics]. Collective accommodation establishments [online]. [cit. 17.12.2019].
Available at: https://vdb.czso.cz/vdbvo2/faces/en/index. jsf?page $=$ statistiky\# katalog $=31739$

DAS, D., SHARMA, S. K., MOHAPATRA, P. K., SARKAR, A. (2007): Factors influencing the attractiveness of a tourist destination: A case study. Journal of Services Research, 7(1): 103-134.

DE SIMONE, E., CANALE, R. R., DI MAIO, A. (2019): Do UNESCO World Heritage Sites Influence International Tourist Arrivals? Evidence from Italian Provincial Data. Social Indicators Research, 146: 345-359.

DESTATIS (2019): Gastgewerbe, Tourismus: Übernachtungen in Beherberungsbetrieben [online]. [cit. 17.12.2019]. Available at: https://www.destatis. de/DE/Themen/Branchen-Unternehmen/GastgewerbeTourismus/_inhalt.html

DUMBROVSKÁ, V., FIALOVÁ, D. (2014): Tourist intensity in capital cities in Central Europe: Comparative analysis of tourism in Prague, Vienna, and Budapest. Czech Journal of Tourism, 3(1): 5-26.

EUROSTAT (2019): Culture statistics [online]. [cit. 10.04.2021]. Available at: https://ec.europa.eu/ eurostat/documents/3217494/10177894/KS 01-19-712-EN-N.pdf/915f828b-daae-1cca-ba54a87e90d6b68b?t=1571393532000

EUROSTAT (2021a): Urban Audit - Culture and tourism cities and greater cities - Number of bed-places in tourist accommodation establishments [online]. [cit. 10.04.2021]. Available at: https://ec.europa.eu/eurostat/ databrowser/view/URB_CTOUR_custom_1237092/ default/table?lang $=$ en

EUROSTAT (2021b): Tourism statistics - Nights spent at tourist accommodation establishments [online]. [cit. 10.04.2021]. Available at: https://ec.europa.eu/ eurostat/statistics-explained/index.php?title=Tourism statistics_-_nights_spent_at_tourist_accommodation_ establishments

EUROSTAT (2021c): Main population - Population by age group (tps00010) [online]. [cit. 10.04.2021]. Available at: https://ec.europa.eu/eurostat/databrowser/view/tps00010/ default/table?lang=en

EUROSTAT (2021d): Main population - Population on 1 January (tps00001) [online]. [cit. 10.04.2021]. Available at: https://ec.europa.eu/eurostat/databrowser/view/tps00001/ default/table?lang $=$ en

EUROSTAT (2021e): Economy and finance - GDP per capita in PPS (tec00114) [online]. [cit. 10.04.2021]. Available at: https://ec.europa.eu/eurostat/databrowser/view/tec00114/ default/table?lang=en

EUROSTAT (2021f): Urban Audit - City Statistics: Population on 1 January by age groups and sex functional urban areas [online]. [cit. 10.04.2021]. Available at: https:/ec.europa.eu/eurostat/databrowser/ view/urb_lpop1/default/table?lang=en

EUROSTAT (2021g): Air Transport - Airline traffic data by main airport [online]. [cit. 10.04.2021]. Available at: https://ec.europa.eu/eurostat/databrowser/view/AVIA PAOAC_custom_1251681/default/table?lang=en

EUROSTAT (2021h): METROREG - Economic Accounts by metropolitan regions [online]. [cit. 10.04.2021]. Available at: https:/ec.europa.eu/eurostat/databrowser/ 
view/MET_10R_3GDP_custom_1236660/default/ table?lang $=$ en

EUROSTAT (2021i): Urban Audit - City Statistics: Population on 1 January by age groups and sex - cities and greater cities [online]. [cit. 10.04.2021]. Available at: https://ec.europa.eu/eurostat/web/cities/data/database

FERRANTE, M., ABBRUZZO, A., DE CANTIS, S. (2017): Graphical models for estimating network determinants of multi-destination trips in Sicily. Tourism Management Perspectives, 22: 109-119.

FSO (2019): Major regions: Hotel accommodation: monthly overnight stays by major region, 2019-2020 [online]. [cit. 17.12.2019]. Available at: https://www.bfs.admin.ch/ bfs/en/home/statistics/tourism/tourist-accommodation/ hotel-accommodation/major-regions.html

GUIRAO, B., CAMPA, J. L. (2014): The construction of a HSR network using a ranking methodology to prioritise corridors. Land Use Policy, 38: 290-299.

HALL, D. (2000): Cross-border movement and the dynamics of transition processes in Southeastern Europe. GeoJournal, 50(2/3): 249-253.

HALL, D. R. (1991): Tourism and economic development in Eastern Europe and the Soviet Union. London, Belhaven Press.

HÄUFLER, V. (1955): Horské oblasti v Československu a jejich využití. Prague, Czechoslovak Academy of Sciences.

HSCO (2019): Time series of annual data - Tourism, catering [online]. [cit. 17.12.2019]. Available at: https://www.ksh. hu/stadat_annual_4_5_o

ICCA (2019): 2018 ICCA Statistics Report: Country \& City Rankings [online]. [cit. 10.04.2021]. Available at: http:// www.iccaworld.org/dcps/doc.cfm?docid $=2321$

IPK INTERNATIONAL (2020): ITB World Travel Trends Report 2020 online]. [cit. 10.08.2021]. Available at: https:/www.itb.com/itb/downloads-englisch/itb-worldtravel-trends-report-2020.pdf

IVY, R. L., COPP, C.B. (1999): Tourism patterns and problems in East Central Europe. Tourism Geographies, 1(4): 425-442.

JANSEN-VERBEKE, M., SPEE, R. (1995): A regional analysis of tourist flows within Europe. Tourism Management, 16(1): 73-80.

KANG, S., LEE, G., KIM, J., PARK, D. (2018): Identifying the spatial structure of the tourist attraction system in South Korea using GIS and network analysis: An application of anchor-point theory. Journal of Destination Marketing and Management, 9: 358-370.

KHALID, U., OKAFOR, L. E., SANUSI, O. I. (2021): Exploring Diverse Sources of Linguistic Influence on International Tourism Flows. Journal of Travel Research, 00(0): 1-19.

KHAN, S. A. R., QIANLI, D., SONGBO, W., ZAMAN, K., ZHANG, Y. (2017): Travel and tourism competitiveness index: The impact of air transportation, railways transportation, travel and transport services on international inbound and outbound tourism. Journal of Air Transport Management, 58: 125-134.

KRAFT, S., HAVLÍKOVÁ, D. (2016): Anytime? Anywhere? The seasonality of flight offers in Central Europe. Moravian Geographical Reports, 24(4): 26-37.
KREŠIĆ, D., PREBEŽAC, D. (2011): Index of destination attractiveness as a tool for destination attractiveness assessment. Tourism: An International Interdisciplinary Journal, 59(4): 497-517.

KULENDRAN, N., KING, M. L. (1997): Forecasting international quarterly tourist flows using errorcorrection and time-series models. International Journal of Forecasting, 13(3): 319-327.

LESJAK, M., NAVRÁTIL, J., PÍCHA, K., GILLIAM, V. L. W. B. (2015): The Predictors of the Willingness to Recommend a Visit for Diversified Tourism Attractions. Czech Journal of Tourism, 4(2): 77-90.

LEW, A., MCKERCHER, B. (2006): Modelling tourist movements: A local destination analysis. Annals of Tourism Research, 33(2): 403-423.

LI, X., MENG, F., UYSAL, M. (2008): Spatial pattern of tourist flows among the Asia-Pacific countries: An examination over a decade. Asia Pacific Journal of Tourism Research, 13(3): 229-243.

LIU, F., ZHANG, J., CHEN, D. (2010): The characteristics and dynamical factors of Chinese inbound tourist flow network. Acta Geographica Sinica, 65(8): 1013-1024.

LOHMANN, G., ALBERS, S., KOCH, B., PAVLOVICH, K. (2009): From hub to tourist destination - An explorative study of Singapore and Dubai's aviation-based transformation. Journal of Air Transport Management, 15(5): 205-211.

MANSFELD, Y. (1990): Spatial patterns of international tourist flows: towards a theoretical framework. Progress in Human Geography, 14(3): 372-390.

MARROCU, E., PACI, R. (2013): Different tourists to different destinations. Evidence from spatial interaction models. Tourism Management, 39: 71-83.

MAYER, T., ZIGNAGO, S. (2011): Notes on CEPII's distances measures: The GeoDist database. CEPII Working Paper, 2011(25): 7-12.

MCKERCHER, B., LEW, A. A. (2004): Tourist Flows and the Spatial Distribution of Tourists. In: Lew, A. A., Hall, C. M., Williams A. M. [eds.]: A Companion to Tourism. New Jersey, Blackwell Publishing: 36-48.

NOVÁČEK, A. M. [ed.] (2012): Dualita Evropy: historickogeografická analýza. Praha, Česká geografická společnost.

NOVOTNÁ, M., KUBÍČKOVÁ, H., KUNC, J. (2021): Outdoor excitement in homeland? Opportunities and threats to balloon tourism in the Czech Republic during the coronavirus outbreak. Journal of Outdoor Recreation and Tourism, 36(2021): 1-5.

OPPERMANN, M. (1993): Tourism space in developing countries. Annals of Tourism Research, 20: 535-556.

PAGE, S. (2005): Transport and tourism: Global perspectives. London, Pearson Education.

PENG, H., ZHANG, J., LIU, Z., LU, L., YANG, L. (2016): Network analysis of tourist flows: a cross-provincial boundary perspective. Tourism Geographies, 18(5): 561-586.

PRIDEAUX, B. (2005): Factors affecting bilateral tourism flows. Annals of Tourism Research, 32(3): 780-801.

REITSAMER, B. F., BRUNNER-SPERDIN, A., STOKBURGER-SAUER, N. E. (2016): Destination attractiveness and destination attachment: The 
mediating role of tourists' attitude. Tourism Management Perspectives, 19: 93-101.

ŠAUER, M., BOBKOVÁ, M. (2018): Tourist flows between Central European metropolises (In the context of metropolitan processes). Geographia Technica, 13(2): 125-137.

ŠAUER, M., PAŘIL, V., VITURKA, M. (2019): Integrative potential of Central European metropolises with a special focus on the Visegrad countries. Technological and Economic Development of Economy, 25(2): 219-238.

SEYFI, S., RASTEGAR, R., RASOOLIMANESH, S. M. HALL, C. M. (2021): A framework for understanding media exposure and post-COVID-19 travel intentions. Tourism Recreation Research, ahead-of-print: 1-6.

SHAO, Y., HUANG, S. S., WANG, Y., LI, Z., LUO, M. (2020): Evolution of international tourist flows from 1995 to 2018: A network analysis perspective. Tourism Management Perspectives, 36: 100752.

SOSR (2019): Visitors in tourist accommodation establishments [online]. [cit. 17.12.2019]. Available at: http://statdat.statistics.sk

STATISTICS AUSTRIA (2019): Tourism [online]. [cit. 17.12.2019]. Available at: https://www.statistik.at/web_ en/statistics/Economy/tourism/index.html/

STATISTICS POLAND (2019): Culture. Tourism. Sport [online]. [cit. 17.12.2019]. Available at: https://stat.gov. pl/en/topics/culture-tourism-sport/

STB (2019): Tourism in numbers [online]. [cit. 17.12.2019]. Available at: https://www.slovenia.info/en/business/ about-slovenian-tourist-board

ŠVEDA, M., MADAJOVÁ, M. S., BARLIK, P., KRIŽAN, F., ŠUŠKA, P. (2020): Mobile phone data in studying urban rhythms: Towards an analytical framework. Moravian Geographical Reports, 28(4): 248-258.
TOURMIS (2019): Marketing-Information-System for tourism managers. Wien: MODUL University Vienna [online]. [cit. 17.12.2019]. Available at: http://www. tourmis.info/

UNESCO (2021): World Heritage List [online]. [cit. 10.04.2021]. Available at: https://whc.unesco.org/en/list/

UNWTO (2019): Yearbook of Tourism Statistics, Data 20132017, 2019 Edition. Madrid, UNWTO.

UNWTO (2021): International Tourism Highlights, 2020 Edition [online]. [cit. 10.04.2021]. Available at: https:// www.e-unwto.org/doi/pdf/10.18111/9789284422456.

UNWTO/WTCF (2018): UNWTO/WTCF City Tourism Performance Research [online]. [cit. 08.08.2021]. Available at: https://www.e-unwto.org/doi/ book/10.18111/9789284419616

VITURKA, M., PAŘIL, V., TONEV, P., ŠAŠINKA, P., KUNC, J. (2017): The Metropolisation Processes - A Case of Central Europe and the Czech Republic. Prague Economic Papers, Praha, 26(5): 505-522.

WILLIAMS, A. M., BALÁŽ, V. (2002): The Czech and Slovak Republics: Conceptual issues in the economic analysis of tourism in transition. Tourism Management, 23(1): 37-45.

WILLIAMS, A. M., ZELINSKY, W. (1970): On Some Patterns in International Tourist Flows. Economic Geography, 46(4): 549-567.

XING-ZHU, Y., QUN, W. (2014): Exploratory space-time analysis of inbound tourism flows to China cities. International Journal of Tourism Research, 16(3): 303-312.

YANG, Y., WONG, K. K. (2013): Spatial distribution of tourist flows to China's cities. Tourism Geographies, 15(2): 338-363.

ZHANG, J., JENSEN, C. (2007): Comparative advantage: explaining tourism flows. Annals of tourism research, 34(1): 223-243.

\section{Please cite this article as:}

ŠAUER, M., VYSTOUPIL, J., NOVOTNÁ, M., WIDAWSKI, K. (2021): Central European tourist flows: Intraregional patterns and their implications. Moravian Geographical Reports 29(4): 278-291. doi: https://doi.org/10.2478/mgr-2021-0020 